\title{
気象予報情報の潮流予測への 適用に関する研究 STUDY ON NUMERICAL PREDICTION OF TIDAL CURRENT USING FORECATED WEATHER DATA
}

\author{
西田渉 1 野口正人 2 - Dimitri P. Solomatine ${ }^{3}$ \\ Wataru NISHIDA, Masato NOGUCHI and Dimitri P. SOLOMATINE

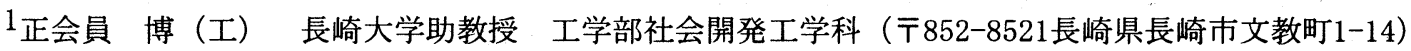 \\ 2 フェロー 工博 長崎大学教授 工学部社会開発工学科（同上） \\ ${ }^{3} \mathrm{Ph} . \mathrm{D}$, Associate Professor, UNESCO-IHE Institute for Water Education, Department of \\ Hydroinformatics and Knowledge Management (P. 0. Box 3015, 2601 DA, Delft, The Netherlands)
}

\begin{abstract}
The environmental impact assessment is becoming very important with increased public awareness to the environmental issues. In many cases, future conditions of water environment are evaluated referring to the results obtained from numerical simulations that are carried out based on the possible scenario. However, it is quite difficult to set some computational conditions in detail. In this study, to predict the tidal currents at coastal area, firstly, the numerical simulation model has been developed. This model was calibrated using global optimization technique named ACCO. Its accuracy of predicted result related to the tidal motion in Shimabara Bay was shown. Following, the tidal current simulation was curried out using weather data forecasted by mesoscale model, MSM. The calculated results show that the tidal motion of this bay is changed strongly affected by the wind blowing on the water surface, and temporal and spatial variation of meteorological condition should be adequately taken into account for the precise prediction of material transportation. Furthermore, from the results obtained by simulations regarding the uncertainty of forecasted weather data, it seems that uncertainty analysis will be required to evaluate the accuracy of predicted results.
\end{abstract}

Key Words : numerical simulation, tidal current, forecasted weather data

\section{1. はじめに}

沿岸域の環境開発を実施する上で，環境影響に関わる 事前評価が大切であることは言うまでもない，また，環 境に対する社会的な関心が高まっている昨今では, 開発 行為に伴う影響を軽减させるための事後の管理も重要に なっている，一般に，事後の環境の状態は，環境影響評 価の中で, 数値シミュレーション等によって, 予測・評 価されているわけである. 一方で, 事前予測に関連して は, その実施に必要な, 気象条件や，あるインパクトに 対する環境影響の発現の速さといった事柄に関して, データの蓄積と解析によって多くの科学的知見が得られ てきているとはいえ, それらの中長期的な変動を正確に 見積もることは簡単なことではない. 著者らは, 沿岸域 における事後の環境管理をより適切に行うには, 当該水 域周辺における流れの状態を, 逐次的に考慮した管理が
必要であると考え, これまでに, 数值シミュレーション モデルを用いた潮流の実時間的な予測手法の構築を試み てきている1,2).ここで，実時間的な予測に限ったことで はないが，潮流の数值シミュレーションの際には，開境 界での潮位や海面上を吹く風の時空間分布等が計算条件 に適切に反映されておかね水ばならない。ささに，潮流の 実時間的，短時間的な予測にあっては，上述の条件をど のように見積もっておくかが問題となる.

ところで, 日本周辺における気象の実況は, 現在, 地 上・海上気象観測や気象レーダ観測等による計測結果に 基づいて把握され，それと併せて，気象庁においては， 数值予報モデルを用いて気象現象に関する予測シミュ レーションを行っている3,4,5). 後述されるように, この 予測データの一部は, オンラインで入手可能であり, 海 域上での気象要素の予報值もデータに含められているこ とから，潮流の予測に有用な情報資源になるものと思わ れる. 本研究では, 上述の特徴をもつ気象予報データの 
活用を図ることとし，このデータの潮流のシミュレー ションへの適用を試みる．また，予測計算の実施にあ たって生じる問題点について検討することとした.

\section{2. 潮流の数値モデルの概要と検定}

\section{（1） 数値モデルの概要}

潮流の予測モデルは，これまで著者らによって開発さ れてきた三次元レベルモデルである. ここで，流れの基 礎方程式としては，以下に記される連続方程式と運動方 程式とが取り上げられている．また，流体の密度は，水 温，塩化物イオン濃度によって変化するものとされてお り，各物理量に関する収支式も基礎式に含められている。 連続方程式

$$
\frac{\partial u h}{\partial x}+\frac{\partial v h}{\partial y}+w_{l-l}-w_{l}=0
$$

運動方程式

$$
\begin{array}{r}
\frac{\partial u h}{\partial t}+\frac{\partial(u \cdot u h)}{\partial x}+\frac{\partial(u \cdot v h)}{\partial y}+\left.u w\right|_{1-1}-\left.u w\right|_{1} \\
=f v h-\frac{1}{\rho_{0}} \frac{\partial P}{\partial x}+\frac{\partial}{\partial x}\left(\varepsilon_{x} h \frac{\partial u}{\partial x}\right)+\frac{\partial}{\partial y}\left(\varepsilon_{y} h \frac{\partial u}{\partial y}\right) \\
+\left.\varepsilon_{z} \frac{\partial u}{\partial z}\right|_{l-1}-\left.\varepsilon_{z} \frac{\partial u}{\partial z}\right|_{1} \\
\frac{\partial v h}{\partial t}+\frac{\partial(v \cdot u h)}{\partial x}+\frac{\partial(v \cdot v h)}{\partial y}+\left.v w\right|_{l-1}-\left.v w\right|_{1} \\
=-f u h-\frac{1}{\rho_{0}} \frac{\partial P}{\partial y}+\frac{\partial}{\partial x}\left(\varepsilon_{x} h \frac{\partial v}{\partial x}\right)+\frac{\partial}{\partial y}\left(\varepsilon_{y} h \frac{\partial v}{\partial y}\right) \\
\quad+\left.\varepsilon_{z} \frac{\partial v}{\partial z}\right|_{l-1}-\left.\varepsilon_{z} \frac{\partial v}{\partial z}\right|_{l}
\end{array}
$$

ここに, $u, v, w: x, y, z$ 軸方向の流速, $h:$ 層厚, $f:$

$(=2 \omega \cdot \sin \varphi)$ コリオリの係数 $(\omega$ : 地球の自転の角速度, $\varphi$ : 緯度) $, \rho:$ 流体の密度, $\rho_{0}$ : 流体の基淮密度(水温 $20^{\circ} \mathrm{C}$ における水の密度),$g$ : 重力加速度, $P$ : 流体の圧 力, $\varepsilon_{x}, \varepsilon_{y}, \varepsilon_{z}: x, y, z$ 軸方向の渦動粘性係数, である.

水平方向の渦動粘性係数はPrandt 1 の混合距離モデル の形で評価し，乱流拡散係数はRichardsonの $4 / 3$ 乗則に よって与えることにした．鈶直（z軸）方向については, Munk and Anderson 型のRichardson数の関数として評価 されている6). 水底面での摩擦応力については, Manning 則が適用している. また，水面上の気流が流れに及ぼす 影響は風速を用いて次式のとおりに評価された.

$$
\left(\tau_{\mathrm{sx}}, \tau_{\mathrm{sy}}\right)=\gamma_{\mathrm{a}}^{2} \rho_{\mathrm{a}}\left(W_{x}^{2}+W_{y}^{2}\right)^{0.5} \cdot\left(W_{x}, W_{y}\right)
$$

ここに, $\gamma_{\mathrm{a}}$ : 自由水面上での抵抗係数, $\rho_{\mathrm{a}}$ : 空気の密 度, $W_{x}, W_{y}$ : 水表面上を吹く風の $x, y$ 軸方向の風速, で ある. 各基礎方程式の離散化にあたっては, 差分格子に Staggered 格子系を採用した上で, 陽形式の有限差分法 によって離散化されており，空間差分にはDoner Cell法 が，時間軸の差分にはLeap-Frog法が適用されている.

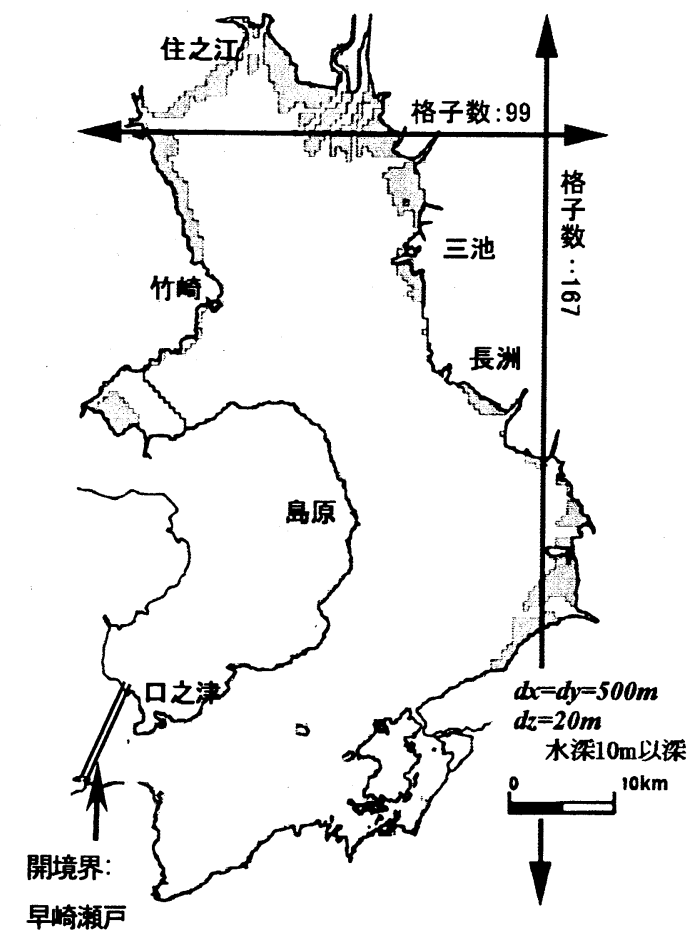

図-1 計算領域の概要図

\section{（2）計算領域}

本研究では，計算の対象領域として，島原湾を取り上 げている. 本領域の地形データについては, 今回, 一般 に公開されているデータを有効活用する体制を整えるこ とも研究の目的の一つに考えており, 海上保安庁海洋情 報部から配信されている500mのメッシュ水深データ (JODC-Expert Grid data for Geography 500m 以降, J-EGG500 と記す)を海底地形のデータとして利用するこ とにした ${ }^{7)}$. J-EGG500は, 各種の海洋調査機関によって 計測された水深測量データを, 水平方向に約 $500 \mathrm{~m}$ 間隔の メッシュ情報レしたデータセットである.このデータは, 該当地点の水深が緯度・経度をべースに整理されている ので, 緯度・経度系から潮流の計算に採用されている直 線直交座標系への変換をWGS-84測地系でガウス・ク リューゲル図法によって行うことにした。なお，JEGG500のデータのみでは, 海域と陸域との境界を特定で きないために, 別途, 市販の電子地図帳から境界座標の 情報(経度, 緯度)を取得することで, 計算に必要な地形 情報を補完している，また，J-EGG500では，水深の最小 単位が1mであることから, 島原湾沿岸の干潟のような, 比較的平坦な地形については, 地盤高の緩やかな変化が 十分には表現されていない. そのため, このような領域 については, 海図を参考に地形情報の補間・修正処理が 行われた。

以上の手続きで得られた計算領域の概要は, 図一 1 に 示されるとおりである，早崎瀬戸に相当する開境界には, 潮位変化が計算条件として与えられ，島原湾南部の八代 海につながる瀬戸には弱い反射波の条件が与えられた。 空間方向の差分間隔は, 水平方向に $\mathrm{dx}=\mathrm{dy}=500 \mathrm{~m}$ とされ 
ている．鉛直方向については，島原湾湾奥で潮差が大き いことを考慮して, T.P. $-10.0 \mathrm{~m}$ 以浅を表層とし，それ以 深を一様の層厚 $(\mathrm{dz}=20.0 \mathrm{~m})$ に分割している. 時間差分 間隔は, $\mathrm{dt}=2.0 \mathrm{sec}$ とれた.

\section{（3） モデルの検定}

数值モデルの現地一の適用に先立って, 本モデルに含 まれるモデルパラメータの同定を行った. 対象としたモ デルパラメータは, 水平方向並びに鉛直方向の混合距離 モデルにある混合長に相当する係数 $\left(l_{h}, l_{v}\right)$ とManningの 粗度係数 $(n)$ である. なお, 粗度係数は, 全計算領域体 に一定值を与えている. 検定は, 開境界にM2潮に相当す る潮位を与えた計算から求められた島原湾の主要港湾に おける潮差と潮時差に基づいて行われた. 検定手法とし ては, Solomatineによって提案された大域的最適化手法 の一つであるAdaptive Cluster Covering Method が適 用されている ${ }^{8)}$. 著者らは，これまでにも他の最適化手 法を用いた数値モデルの自動検定を試みているが，本手 法を採用したのは, 最適解付近への収束が比較的早く, 今回の様に，一回のシミュレーションに要する時間が比 較的長い場合には, 検定時間を短縮させる点から有利で あると判断した理由によっている9). なお，この検定で は, 試行点並びにクラスターの数を 36 点, 3 個としてい る. 結果の適合性については, 基本的に, 計算値と参考 值苗 との差の二乗值の総和で評価されているが，ここで は, 更に, 潮差と潮時差の空間的な再現性を評価結果に 反映させるための重み関数が導入されている. 潮差と潮 時差は, 潮流のシミュレーションを開始してから 4 潮汐 以降の結果を調和解析して求められている.

モデルの検定の結果を示すと表一1のとおりである. 三つのモデルパラメータは, $n=0.017 \mathrm{ec} / 1 / 3, l_{h}=35.53 \mathrm{~m}$, $l_{v}=3.71 \mathrm{~m}$ の様に探索された. 検定は島原, 三池, 竹崎, 住之江の各港湾でのデータについて行われた. 同表には, 検証用のデータとして長洲港での結果も記されている. 参考值と比べると, 潮時差が全体的に10分程度遅れてい るものの, 島原湾での潮差は湾口から湾奥にかけて次第 に大きくなり, 住之江港付近で最大となることが本モデ ルによって表現されていることが分かる. 計算值と参考 值との差については, 開境界の設定位置や, 住之江港付 近にあっては流入河川との水収支のモデル化がなされて いない，等に起因しているとも考えられる，なお，潮汐 流の時空間分布については, 十分な数のデータを準備で

表一 1 潮差と潮時差

\begin{tabular}{|c|c|c|c|c|c|}
\hline & 島原 & 三池 & 竹崎 & 住之江 & 長洲 \\
\hline \multirow{2}{*}{$\begin{array}{c}\text { 潮差 } \\
\text { (m) }\end{array}$} & 2.64 & 2.98 & 3.01 & 3.22 & 2.78 \\
\cline { 2 - 6 } & 2.69 & 3.13 & 3.13 & 3.44 & 2.93 \\
\hline \multirow{2}{*}{$\begin{array}{c}\text { 潮時差 } \\
\text { (分) }\end{array}$} & 18.8 & 23.8 & 24.0 & 51.5 & 20.3 \\
\cline { 2 - 6 } & 10 & 15 & 15 & 30 & 15 \\
\hline
\end{tabular}

※計算值 : 上段, 参考值 : 下段(潮位表改正数から算出
きなかったために検定対象の項目に上げておらず，再現 性の定量的な評価は行っていない.これらについては, 再現性向上のための課題となっていることを記しておく.

\section{3. 気象予報データを用いた潮流解析}

\section{（1）気象予報データの概要}

本研究で利用する気象予報データは, 気象庁新数值解 析予報システムによって解析された結果であり, 気象業 務法に基づいて, 気象庁から気象業務支援センターを経 由して配信される数值予報データである ${ }^{4), 11}$.

このデータには, 予報結果の利用目的に応じて, 予報 範囲や最大予報時間の異なる数種類の予報モデルによっ て算出された予報值があるが，ここでは，それらの中で, 空間方向の予報データの間隔が最小であるメソ数值予報 モデル (Mesoscale Model 以降, MSMと記す) の予報值 が用いられた. MSMによる気象現象に関する予測計算は, 東経: $120^{\circ} \sim 150^{\circ}$, 北緯: $22.4^{\circ} \sim 47.6^{\circ}$ の領域を 対象に, 緯度・経度の格子系に基づいて実施されている. 予報計算は，00,06,12,18UTC（協定世界時）を初期時刻 として, 一日あたり 4 回行われている. 予報データの間 隔は1時間であり，18時間後までの気象変化が予測され ている. 予報される気象変数要素は, 地上物理量として, 海面更正気圧, 風, 気温, 相対湿度, 時間降雨量, 雲量 であり，これらの結果が，指定の資料通報式に変換され ている. なお, 定時に行われる 4 回の計算では, 四次元 変分法による初期值のデータ同化がなされており, 予報 精度の向上が図られている.MSM予報值の潮流計算への 利用にあたっては, MSMの格子間隔が経度方向に0.125度, 緯度方向に0.10度（地上間隔とすると約 $10 \mathrm{~km}$ ）であり， J-EGG500に基づく空間解像度との間に20倍程度の差があ ることから, 双一次内挿によって計算格子点での值が求 められた。

\section{（2）開境界条件の評価}

図一1に示される海域を対象にした潮流の計算では, 開境界である早崎瀬戸で潮位変化が与えられる. 計算領 域での気象変化を考慮した潮流解析では, 潮位条件に気 象状態の変化による偏差成分も考慮されねばならない。 本研究では, 口之津港で観測された潮位偏差をニューラ ルネットワークを使って解析し, 後述される潮流のシ ミュレーションの境界条件に反映させることとした.

ここで，解析に用いた潮位偏差の実測資料は，気象庁 から報告されている2004年 5 月 7 日9:00から 6 月26日 12:00までの 1 時間間隔のデータである ${ }^{12)}$.ニューラル ネットワークは, 中間層を 1 層とする 3 層階層型とされ, 中間層には, 8個のユニットが配されている. バックプ ロパゲーションについては, 慣性項を導入することで, 学習効率の高速化が図られている. 入力データについて 
は, 当初, 大気圧, 緯度・経度方向の風速, 時間降雨量, 過去 6 日の日降雨量, として解析を行っていたが，潮位 偏差の実測值には，M2潮に連動するような変動成分が存 在し，上記の諸量だけでは十分に評価できなかったため, 更に潮位と天文推算潮位から算出した潮位の時間変化率 を入力データに加えて解析されている.

以上の条件によって, 求められた潮位偏差の計算結果

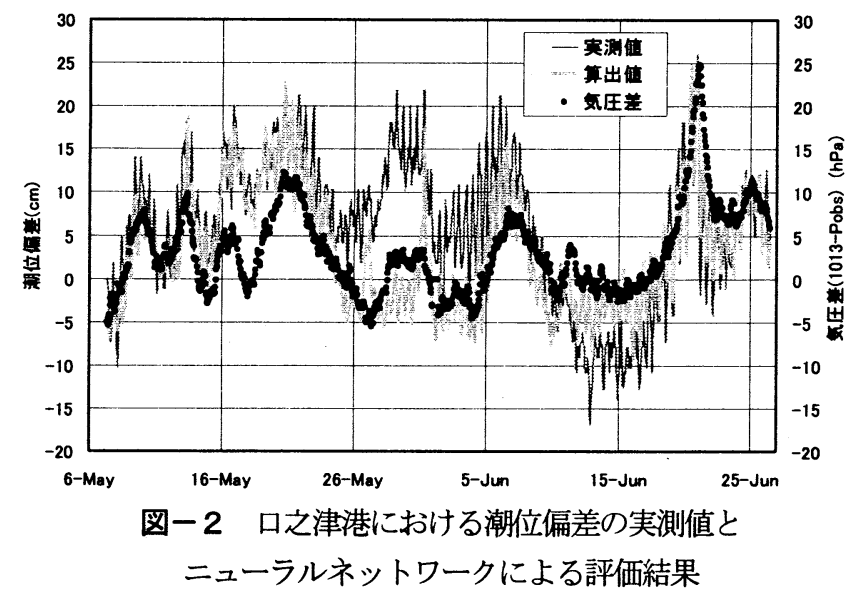

を示すと図ー 2 のとおりである. 同図には，基準大気圧 を1013hPa とした時の実測値との差 $\left(1013-\mathrm{P}_{\mathrm{obs}}\right)$ 気圧偏差 が併記されている. ニューラルネットワークの学習回数 は10万回である.この結果によれば，5月26日から 6 月 4 日までの潮位偏差の再現性が乏しい.この期間につい ては, 気圧差の結果からも分かる様に, 当該地域の気象 変化が然程大きくなかったにも拘らず，15〜20 cmの潮位 偏差を生じており, 上記のデータ以外にも考慮されるべ き要因があることを示唆しているものと思われる. 一方 で，この期間を除けば， 5 月末までの変化や 6 月 20 日か ら22日にかけて九州の東方海上を通過した台風 6 号に影 響された潮位の上昇, 細かい変動等を良く評価している ことが分かる. 次節に示される潮流のシミュレーション では, 気象・潮位に関する計算条件から生じる開境界で の潮位偏差を, このニューラルネットワークを用いて評 価することにした.

\section{（3）潮流計算の結果と考察}

潮流のシミュレーションの計算条件に用いられた予報 值は，2004年6月13日00UTCを初期洔刻として予報され た 1 時間毎の物理量である. 図一 3 には，MSMで予報さ れた九州周辺での風速べクトルの空間分布が示されてい る. これに基づいて島原湾付近の予報結果を記すと, 湾 の北部海域では概ね北東からの風が, 南部海域では北寄 りの風が吹くとされている. また，大気圧は約 $1013 \mathrm{hPa}$ であり, 島原湾とその周辺地域に降雨はないものと予報 されている.

ここで，まず，気象条件の導入に伴って生じる島原湾 内の基本的な流況の変化を明らかにするために，先述の 気象条件 (条件(1) と，大気圧を時空間的に一様（1013
$\mathrm{hPa}$ ）且つ無風状態とした条件（条件(2)）の下で計算を 行い, 結果の比較を行った. これら二種類の計算条件か ら得られた流速ベクトルの空間分布を示すと, 図一 4 の とおりである. なお, 二つの結果は, 湾奥部での潮汐が ほほ満潮になった時点に相当している.これらの図から， 与えられた気象条件の変化を受けて, 条件(1)では, 島原 湾の東部並びに湾奥部において, 沿岸に沿って流れる傾 向が強くなっていることが分かる. また, この時, 諌早 湾では, 締切堤の周辺を含めた, 全域で流速が速くなる ようである.ここで, 島原湾における潮位の時間変化を

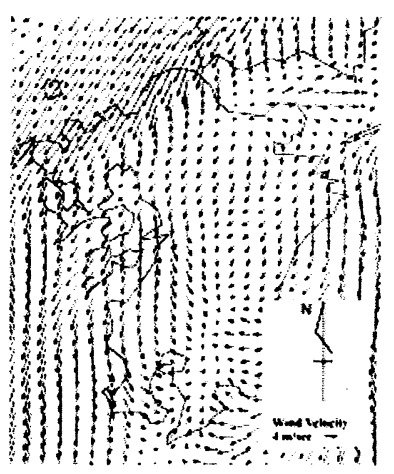

(a) 00 UTC

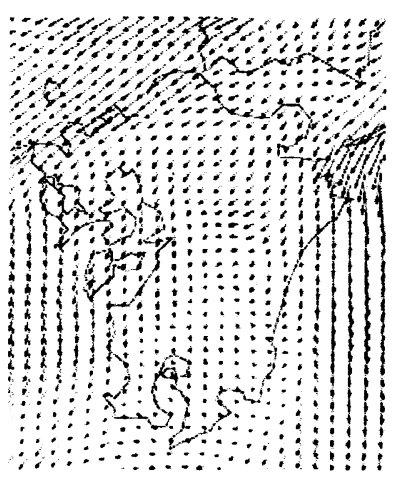

(b) 6 時間予測值
図-3 風速ベクトルの空間分布

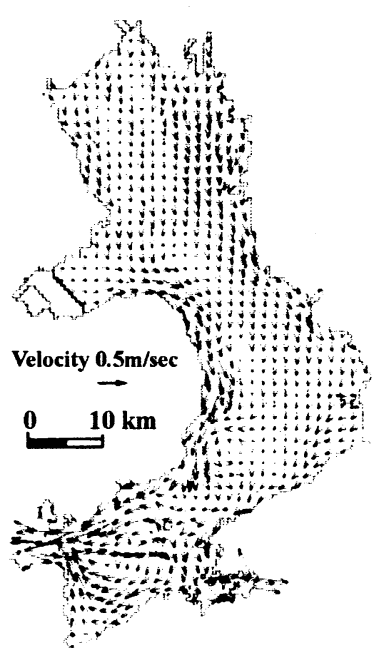

(a) 条件(1)

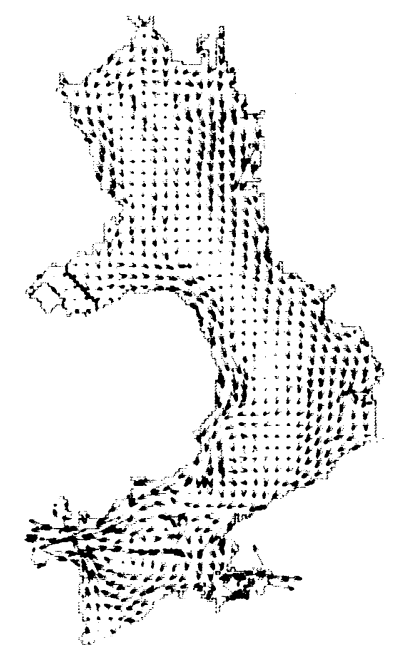

(b) 条件(2)

図-4 流速ベクトルの空間分布

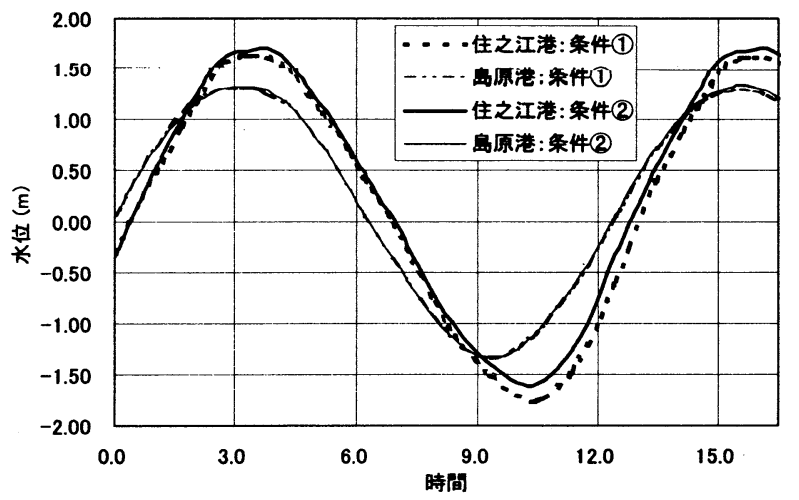

図一 5 潮位の時間変化 


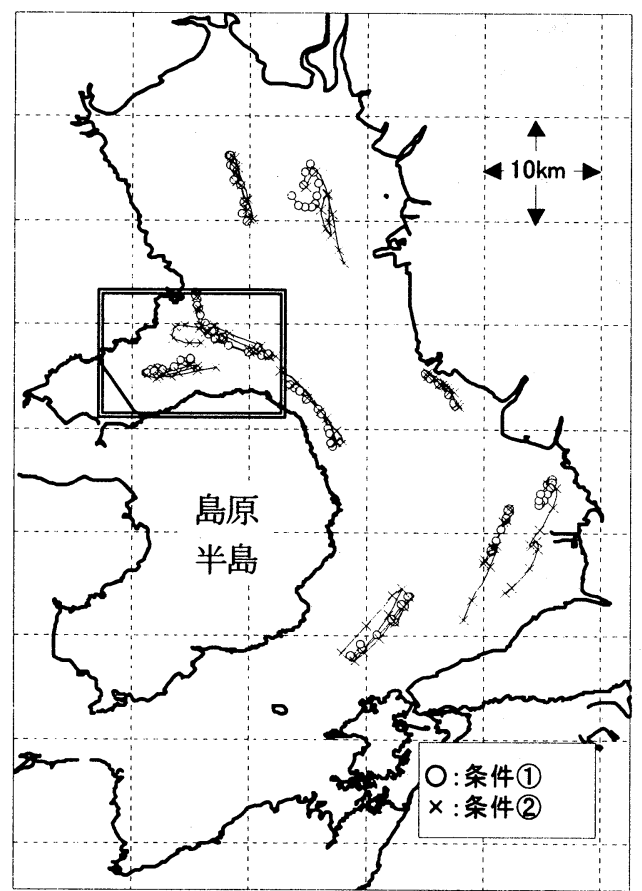

図一 6 水粒子の移動軌跡

(図中の二重枠線は，図一8の参照位置を表す)

示すと図－5のとおりである. 図に示されるように，湾 内の潮位変化の違いは住之江港において顕著であり，条 件(1)の満潮時と干潮時の潮位は，条件(2)に比べて，それ ぞれ $9 \mathrm{~cm}, 15 \mathrm{~cm}$ 低下している. また，条件(1)に用いたMSM の予報結果では，風が島原湾の海面上を，概ね北から吹 くものとされていたこともあり，この風に対して逆向き の潮流が発生する上げ潮時に潮位の変化が遅れ，下げ潮 時には変化が早まることも示されている．住之江港での 潮位の変化は, 当該地点の風と共に, 湾内の潮汐の全体 的な傾向が反映した結果であると推察される，気象条件 を反映した潮流の変化は，図一 6 に示されるように，湾 内における物質の空間的な移動軌跡に大きな違いを生じ させている. 図示された移動軌跡は，水粒子を表層 $(5 \mathrm{~m})$ に設置した時の結果であり，マーカーは 1 時間 2 分毎の 水粒子の位置を表している，すなわち，水粒子は，風に 関する計算条件に影響を受けて，初期に設定された位置 から次第に南下しつつある. この傾向は, 流向と流速に 大きな変化が現れた島原湾の東部沿岸や諌早湾湾口部に おいて顕著であり, 予測位置は最大 $10 \mathrm{~km}$ 程度離れている. 以上の計算結果から，島原湾の潮流は，早崎瀬戸を通じ た外海との水交換によって主に発生していると考えられ るが，一部の海域では，海面上を吹く風によって物質の 流送過程が変化することが了想されるから，島原湾での 潮流や物質の流送状態を精度良く評価するためには，や はり海上の気流の時空間変化を適切に把握し, 計算条件 に取り入れておくことが重要であるといえる.

ところで，気象予報值は，数值モデルによって解析さ れた結果であり，予報間隔が長期になると，ある程度の 予報誤差が生じるものと考えられる．ここで，2004年 6

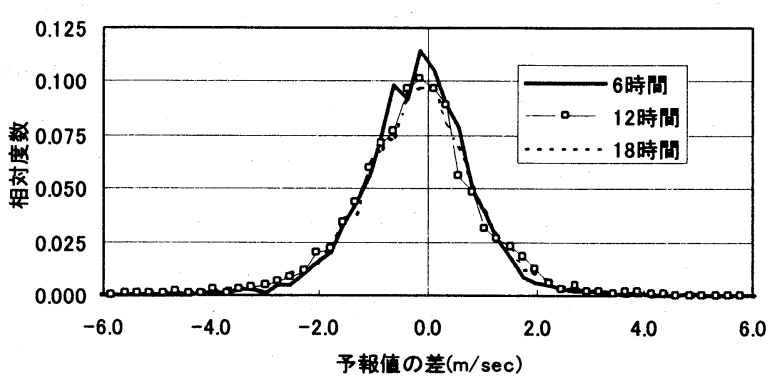

（a）経度方向の風速

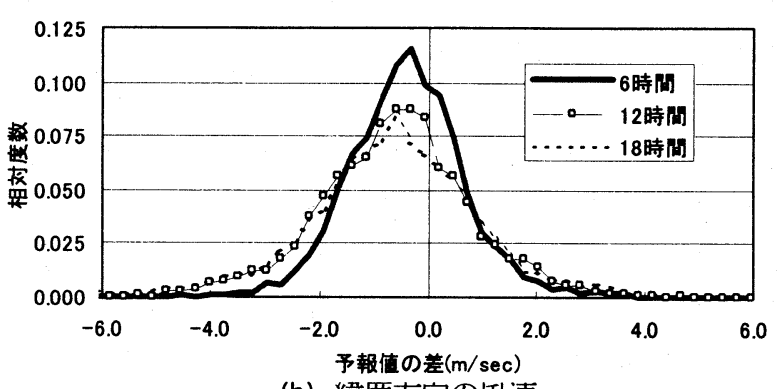

(b) 緯度方向の風速

図-7 予報誤差の頻度分布

（2004年6月 1 日00UTC〜26日 18UTCの結果に基づいて算出）

表一 2 計算条件

\begin{tabular}{|c|c|c|c|c|c|c|}
\hline 条件 & (1) & (2) & (3) & (4) & (5) & (6) \\
\hline 緯線方向成分 & +2 & -2 & +2 & 0 & -2 & 0 \\
\hline 経線方向成分 & +2 & -2 & 0 & +2 & 0 & -2 \\
\hline
\end{tabular}

※各成分の予報值に加えられた変化量 (単位: $\mathrm{m} / \mathrm{sec}$ )

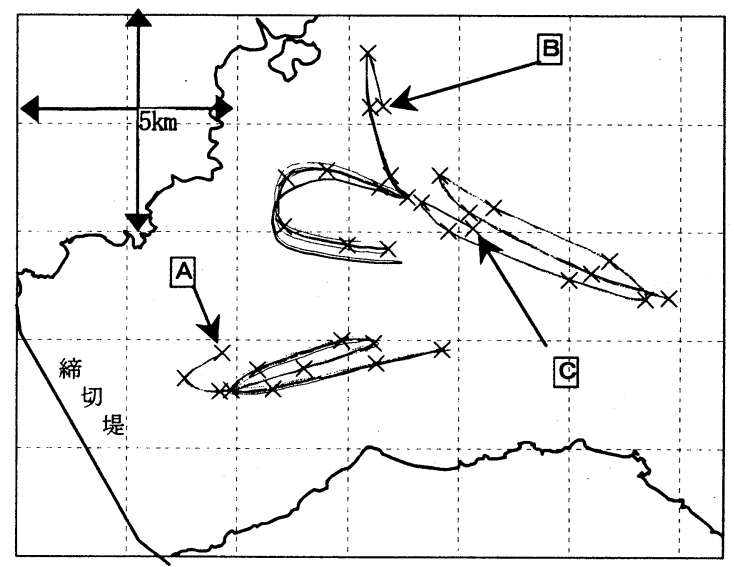

図-8 諌早湾周辺の水粒子の移動軌跡

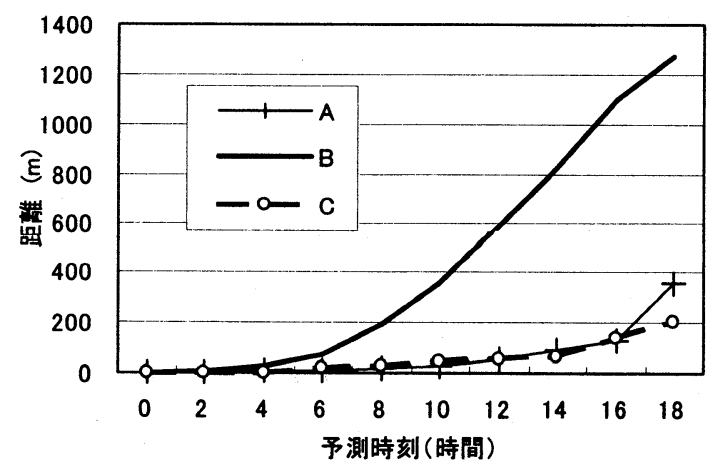

図一 9 マーカー $(\times)$ からの距離の時間変化

（A, B, C は図一 8 の各地点に設定された水粒子に相当する） 
月 1 日から 26 日に取得した島原湾周辺の予報データから 求めた 6 時間, 12 時間, 18時間先の予報結果の誤差を示 すと図一 7 のとおりである. 誤差の算出にあたっては, 一日に 4 回行われる予測計算の初期値を参照している.

この図によると，風速の予報值には，約 $\pm 2.0 \mathrm{~m} / \mathrm{sec}$ の 範囲の差を生じることが多く, 緯度方向の風速について は，経度方向のそれよりも予報時間の長期化するにつれ て, 誤差が大きくなっている.MSMには, 気象予報業務 に必要な総観スケールの気象変化を把握することも目的 の一つとされるだろうから, 限られた特定のGrid Point での結果のみを比較して予報精度を議論することはしな いが，気象予報値の活用にあたっては，こうした予報誤 差に対して相応の注意が必要となる. 以下では, とくに 風の予報值に含まれる予報誤差が潮流シミュレーション 結果の影響に与える影響について検討した。 この計算に あたっては, 図一 7 の結果を参考にして, MSMによる緯 線・経線方向の風の予報值に, $\pm 2.0 \mathrm{~m} / \mathrm{sec}$ の変化を与え た表一 2 に示される 6 種類の条件で行われた.

図一8は, 計算から求められた諌早湾とその周辺海域 における水粒子の移動軌跡である.この図には, 比較の ために，予報值に変化を与えない場合の 2 時間毎の位置 が, マーカー $(\times$ 印) で記されている. 矢印は, 初期の 水粒子の位置を指している. 図一9には, 計算の初期に 諌早湾の各地点に配置された水粒子について, 各予測時 刻における×印からの距離が示されている.これらの図 から, 水粒子の移動軌跡の形状が計算条件毎に大きく異 なることはないものの, それらの予測位置は予報時間の 経過とともに変化し, 注目する場所に応じて, 18時間後 の予測結果には数百mから $1 \mathrm{~km}$ 程度の違いを生じることが 示されている. 諫早湾においては, 湾口北部に与えた水 粒子の移動結果に最も大きな違いが見られる.ここでは, 風の予報誤差によって生じる水の滞留時間の変化等につ いては評価してはいないが，湾内の水質の空間分布に少 なからず影響を与えることも予想されるため, MSM等に よる予報值を利用する際には，こうした予報誤差を認識 した上で, 予測結果を評価する手法の導入が必要になる ものと思われる.

\section{4. おわりに}

本研究では, 内湾を対象にした潮流の数值シミュレー ションに, 気象予報モデルの一つである, MSMによって 求められた気象予報值の適用を試みた。

まず，島原湾を対象に行われた潮流のシミュレーショ ン結果によると，風と大気圧の時空間分布を計算条件に 導入したことで，湾内の流向や潮位の時間変化に顕著な 違いを生じることが示された. ここでは, 限られた予報 値による検討に留まったが，データの蓄積とそれに基づ く解析を進めて，季節的な特性を明らかにする必要があ
る.つぎに, 気象予報值に含まれる予報誤差については, 水粒子の移動結果に関して少なからず影響を及ぼすこと も示された. MSM等による予報値は, 今回実施した計算 例を始めとして，比較的広い海域を対象にした潮流の短 時間的な予測計算に有用な情報資源であると考えられる が，実際的な利用にあたっては，この予報誤差によって 生じる変化に対して, 相応の配慮が必要であると考えら れる. ただ, MSMについては, 平成16年 9 月から非静力 学モデルの運用が開始されており ${ }^{13)}$, こうしたモデルの 精密化による予測精度の向上を期待するところである.

今後は, 実測值との比較を行うことで, 潮流の予測結 果の検証を行う必要がある. また, 気象予報値等, 入力 データに含まれる誤差が予測結果に与える影響について は，その定量化について検討していきたいと考えている.

謝辞 : 気象予報値の利用にあたっては，古谷敏之氏をは じめとします気象業務センター配信事業部の方々に適切 なアドバイスを賜りました. 記して深謝申し上げます.

\section{参考文献}

1）野口正人, 西田渉: 沿岸域の水環境管理の支援を目的とした 流れの数値予測手法の構築, 水工学論文集, 第 44 巻, pp. 1179-1184, 2000.

2) Nishida, W., Noguchi, M. and Nagata, H.: Development of the tidal current forecasting system on internet, Proc. of 6th Int'l Conf. on Hydroinformatics, pp.1941-1946, 2004.

3）二宮洸三 : 数值予報の基礎知識，オーム社，2004.

4）気象庁：新数值予報資料等説明会資料， p. 36，2000.

5）気象庁：新数値予報資料等説明会資料付録，pp. 4-26，2000.

6) 平野敏行監修: 沿岸の環境圈, フジテクノシステム, pp. 674-680, 1998.

7) 日本海洋データセンター: ホームページ 海洋データ情報の 閲覧・提供サービス, URL http://www. jodc. go. jp, 2003.

8) Solomatine, D.P. : Two strategies of adaptive cluster covering with decent and their comparison to other algorithms, $J$. of Global Optimization, Vol.14 (1), pp.55-78, 1999.

9）西田涉,松下紘資, 野口正人, Solomatine, D.P. : 遺伝的アル ゴリズムによる水質モデルの検定とその適用性に関する研究, 水工学論文集, 第48巻(2), pp. 1321-1326, 2004.

10) 海上保安庁: 平成 8 年潮汐表, 第 1 巻, 書誌第781号, 1996.

11）気象庁予報部 : メソ数值予報の実用化に向けて, 数值予報 課報告, 別冊第44号, p. 79, 1998.

12）気象庁：ホームページ 海洋の情報資料, URL http: //www. data. kishou. go. jp, 2004.

13）気象庁予報部：配信資料に関する技術情報（気象編），第 167号, 2004.

(2004.9. 30 受付) 